\title{
Pendidikan Resolusi Konflik Melalui Pembelajaran Multikultural Pada Pendidikan Formal
}

\author{
${ }^{1}$ Rahmad Hidayat, ${ }^{2}$ Bunyamin and ${ }^{3}$ Elly Malihah \\ ${ }^{1}$ rahmadhidayat@upi.edu / rahmadhidayat@fkip.unila.ac.id \\ ²unyaminmaftuh@upi.edu \\ 3 ellyms@upi.edu \\ ${ }^{1}$ Universitas Lampung, ${ }^{2,3}$, Universitas Pendidikan Indonesia
}

\begin{abstract}
Abstrak
Isu keberagaman terkait suku, ras, agama, budaya, bahasa dan sebagainya sering menjadi perhatian berbagai pihak. Sikap yang tidak tepat terhadap isu ini, dapat menjadi masalah di banyak bidang, termasuk pendidikan. Karakteristik siswa yang beragam di sebuah kelas dalam pendidikan formal menjadi masalah dan merupakan tantangan bagi guru untuk memberikan pembelajaran yang tepat. Oleh karena itu, perlu dilaksanakan kajian literatur mengenai pembelajaran multikultural. Penelitian ini bertujuan untuk mengeksplorasi pentingnya pembelajaran multikultural. Penelitian ini adalah penelitian deskriptif kualitatif metode telaah sistematis (systematic review). Sumber informasi berupa dokumen atau literatur terkait konsep pembelajaran multikultural. Dokumen atau literatur dapat berupa buku, artikel ilmiah, proceeding, dan dokumen akademik lainnya. Dokumen atau literatur dianalisis secara sistematis menurut model Creswell. Hasil kajian memberikan gambaran bahwa dalam pendidikan formal diperlukan pembelajaran multikultural untuk menumbuhkan berbagai sikap kebersamaan salah satunya toleransi, sebab pembelajaran multikultural mampu menjadi solusi terbaik dalam menangani keragaman yang ada di kelas. Oleh karena itu, pendidikan di sekolah, baik umum maupun yang berlandaskan agama penting sekali menerapkan pembelajaran multikultural dan mengimplementasikannya melalui berbagai cara dalam proses pendidikan. Pembelajaran multikultural dapat dilaksanakan di berbagai tingkat pendidikan, mulai dari pendidikan dasar hingga perguruan tinggi. Pembelajaran multikultural dapat diintegrasikan pada semua subjek pelajaran. Guna mendukung pelaksanaan pembelajaran multikultural diperlukan suatu pedoman yang dirancang bagi guru baik oleh guru sendiri, tim guru, maupun ahli/peneliti. Selanjutnya perlu dikembangkan model pembelajaran multikultural secara umum di sekolah dan atau secara khusus di setiap mata pelajaran.
\end{abstract}

Kata kunci: multikultural, pembelajaran, pendidikan formal, telaah sistematis.

\section{Pendahuluan}

Keberagaman karakteristik baik individu maupun kelompok orang di dalam masyarakat merupakan isu yang sering muncul dari tahun ke tahun. Keberagaman tampak pada adanya beberapa perbedaan seperti budaya, ras, etnis, suku, bahasa, agama, gender dan lain sebagainya (Capuzzi, 1997: 37). Kondisi tersebut pada akhirnya menciptakan masyarakat yang multicultural, multiracial, multilingual, dan sebagainya. Hal ini terjadi sebagai akibat dari adanya arus mobilitas dan teknologi informasi yang semakin berkembang dengan pesat. Terlebih lagi di era globalisasi yang memberikan konsekuensi terciptanya dunia tanpa tapal batas. Hubungan antar negara, antar daerah, antar budaya bahkan antar individu begitu mudah. Nilai-nilai budaya dari berbagai daerah tentu saja mengalir mengikuti arus tersebut dan memberikan dampak, baik positif maupun negative, termasuk dalam segi kebudayaan.

Menurut ilmu antropologi, kebudayaan adalah keseluruhan sistem gagasan, tindakan dan hasil karya manusia dalam rangka kehidupan masyarakat yang dijadikan milik diri manusia dengan belajar (Koentjaraningrat, 1989: 193). Kebudayaan seringkali juga mempunyai pengertian 
Rahmad Hidayat, Bunyamin, Elly Malihah

Vol 5 No 1

ISSN : 2541-6995

E ISSN : 2580-5517

sebagai hasil dari cipta, rasa dan karsa. Istilah peradaban sering juga digunakan untuk menyebut suatu kebudayaan yang mempunyai sistem teknologi, ilmu pengetahuan, seni bangunan, seni rupa dan sistem kenegaraan. Indonesia merupakan negara yang kaya akan budaya yang khas, budaya daerah menjadi bagian yang membangun budaya nasional. Terkait isu keberagaman dalam hal budaya, perlu ditanggapi sebagai faktor positif. Adanya heterogenitas yang muncul di masyarakat saat ini menjadi kekayaan yang perlu dihargai dan dilestarikan. Harapan ini perlu didukung dengan upaya pembudayaan paradigma tentang keberagaman.

Pradipto (2005) memberikan penjelasan bahwa pembudayaan dapat dimulai dari sekolah, mengingat sekolah memiliki peran strategis dalam proses pembelajaran, di samping keluarga dan masyarakat. Keberagaman dalam pendidikan ada karena pendidikan tidak lepas dari konteks masyarakat. Meskipun demikian, bukan berarti keluarga dan masyarakat dapat melepaskan tanggung jawab dalam upaya pembudayaan yang diharapkan. Proses pembelajaran yang sesuai dengan kebutuhan dan kebudayaan lokal perlu diterapkan di sekolah. Dalam konteks ini, pembelajaran diharapkan lebih menekankan pada penanaman moral dibandingkan dengan polapola pendidikan birokratis yang lebih mengorientasikan pada tampilan kecerdasan pikiran. Untuk menanggapi isu keberagaman sebelumnya, sekolah disarankan oleh beberapa ahli untuk menerapkan pendidikan multikultural.

Pendidikan multikultural merupakan serangkaian konsep, petunjuk tingkah laku dan arena yang secara resmi diformulasi melalui kurikulum, regulasi, metode pembelajaran, kemampuan guru, hubungan antar sekolah dan masyarakat dalam istilah multikulturalisme. Pendidikan yang mengedepankan isu keberagaman dalam masyarakat menjadi inti dari pendidikan multikultural. Kebijakan otonomi pendidikan mendukung upaya yang mengedepankan kepentingan dan keberagaman lokal. Tantangan bagi pendidikan justru muncul ketika dihadapkan pada upaya mempertahankan keutuhan negara. Sekolah seringkali menjadi alat bagi dominansi otoritas nasional yang memikul beban untuk menjaga integrasi bangsa melalui pengajaran. Adanya kurikulum nasional dan standardisasi ujian merupakan contoh konkrit dari kasus tersebut. Hal itu berangkat dari asumsi bahwa keberagaman harus tetap berada dalam keutuhan dan kesatuan, yang pada akhirnya memunculkan monokulturalisme (Kusumariani, 2006: 53).

Arifudin (2007: 222) mendefinisikan pendidikan multikultural sebagai pendidikan untuk atau tentang keragaman kebudayaan dalam merespon perubahan demografis dan kultural lingkungan masyarakat tertentu bahkan dunia secara keseluruhan. Arifudin sepakat dengan pendapat Paulo Freire bahwa pendidikan bukan merupakan menara gading yang berusaha menjauhi realitas sosial dan budaya. Pendidikan menurut Paulo Freire harus mampu menciptakan tatanan masyarakat yang hanya mengagungkan prestise sosial sebagai akibat kekayaan dan kemakmuran yang dialaminya. Istilah pendidikan multikultural dapat digunakan, baik pada tingkat deskriptif dan normatif yang menggambarkan isu-isu dan masalah-masalah pendidikan yang berkaitan dengan masyarakat multikultural. Lebih jauh juga mencakup pengertian tentang pertimbangan terhadap kebijakankebijakan dan strategi-strategi pendidikan dalam masyarakat multikultural.

Keseluruhan subjek di dunia pendidikan merupakan kesatuan dari keberagaman latar belakang, adat istiadat, budaya, etnis, nilai-nilai, dan sebagainya. Santrock (2014: 158) mengatakan bahwa berbagai variasi tersebut perlu dipertimbangkan dalam proses pendidikan terhadap siswa. Pada prosesnya, pendidikan di kelas diperlukan eksplorasi banyak cara secara terus-menerus untuk mendidik siswa dengan berbagai keberagaman karakteristiknya. Secara spesifik, pendidik perlu menemukan cara-cara untuk membuat kelas menjadi relevan bagi semua 
Rahmad Hidayat, Bunyamin, Elly Malihah

Vol 5 No 1

ISSN : 2541-6995

E ISSN : 2580-5517

siswa. Pembahasan keberagaman karakteristik siswa di dalam kelas ini menjadi bagian dari pendidikan yang dilaksanakan secara formal. Dalam hal ini, Joesoef (1992: 67-68) menjelaskan pendidikan formal mengorganisasikan siswa menjadi kelas-kelas dengan tigkatan tertentu dan terikat pada kurikulum yang berlaku. Pendidikan formal ini secara khusus merujuk pada sistem persekolahan. Dengan kata lain, sekolah dan perguruan tinggi adalah tempat yang secara formal diselenggarakannya pendidikan.

Salah satu permasalahan serius yang dihadapi dunia pendidikan Indonesia adalah lemahnya proses pembelajaran. Implementasi kurikulum pembelajaran di sekolah-sekolah masih banyak yang dinilai belum memuaskan (Sanjaya, 2014: 1). Penelitian Mawardi (2014: 107) memberikan gambaran bahwa proses pembelajaran khususnya secara formal di kelas perlu diperbaiki dengan mengacu pada kurikulum yang berlaku. Saat ini, berlaku kurikulum 2013 yang telah beberapa kali direvisi yang menekankan pada standar penguatan proses pembelajaran. Menanggapi kebijakan ini, kreativitas guru (pendidik) sangat perlukan untuk membimbing siswa memperoleh pengalaman belajar yang bermakna (Elihami, 2019: 79). Di samping itu, dengan mempertimbangkan keberagaman karakteristik siswa, strategi pembelajaran kooperatif dan atau kolaboratif dapat menjadi pilihan yang cocok untuk diterapkan (Apriono, 2013: 292).

Sanjaya (2014: 2-3) menambahkan bahwa seiring dengan perkembangan zaman, diperlukan strategi-strategi pembelajaran yang berorientasi pada proses. Penerapan strategi pembelajaran yang berorientasi pada proses masih dinilai belum optimal. Banyak sekolah yang mementingkan hasil daripada proses pembelajaran di mana siswa memperoleh pengalaman belajarnya. Pada kasus ini, di lapangan banyak dijumpai praktik pembelajaran dengan mengerjakan soal-soal latihan ujian akhir sekolah dan atau ujian nasional dengan tujuan mencapai hasil yang terbaik, sehingga pengalaman belajar siswa tidak diperhatikan lebih dalam. Melalui pembelajaran seperti ini, besar kemungkinan materi pembelajaran tidak dapat tersampaikan secara merata kepada semua siswa. Hal ini diindikasikan oleh variasi hasil belajar yang diperoleh siswa, bahkan tidak sedikit siswa yang tidak memenuhi kriteria ketuntasan minimal yang telah ditetapkan meskipun penetapan kriteria ketuntasan minimal ini telah memperhatikan keberagaman karakteristik siswa. Dari kenyataan ini, sekolah dan guru masih dituntut untuk menemukan cara inovatif yang tepat agar tujuan pembelajaran dapat tercapai dengan optimal.

Longworth dalam Santrock (2014: 159) berdasar pengalaman mengajarnya di sekolah tinggi selama beberapa tahun menyatakan bahwa kunci untuk meningkatkan hubungan antarsiswa dengan latar belakang yang berbeda-beda adalah pemahaman. Pemahaman ini membutuhkan waktu bersama siswa dan mengenal siswa dengan lebih baik lagi, khususnya tentang bagaimana siswa berpikir dan merasa. Pemahaman siswa di dalam kelas secara komprehensif dapat dilakukan dengan penerapan pendidikan multikultural. Pendidikan multikultural adalah pendidikan yang menghargai keberagaman dan mencakup perspektif dari berbagai kelompok budaya secara teratur. Lebih dalam lagi, Shen (2019: 41-42) menambahkan bahwa pendidikan multikultural tidak hanya mencakup fakta budaya yang berbeda-beda, tetapi juga terkait bagaimana proses menerima, menghargai, mengapresiasi, dan mengungkapkan perbedaan-perbedaan tersebut tanpa terpengaruh latar belakangnya (etnis, ras, agama, gender, dsb.). Hoon (2017: 489) menekankan bahwa konsep multikulturalisme perlu diperhatikan secara serius dalam praktik kebijakan di Indonesia. Dalam hal ini, pendidikan formal diatur melalui kurikulum yang merupakan bagian dari kebijakan pendidkan yang berlaku di Indonesia, sehingga pendidikan multikultural perlu mendapat perhatian khusus. 
ISSN : 2541-6995

E ISSN : 2580-5517

Pelaksanaan pembelajaran multikultural menuntut siswa untuk saling mengenal dengan guru sebagai perantara. Pemahaman latar belakang khususnya budaya merupakan aspek penting dari pendidikan multilultural yang bertujuan untuk membuat hubungan dengan latar belakang budaya siswa (Gollnick \& Chinn, 2017: 12-13). Guru memiliki peran sentral dalam pemahaman budaya antarsiswa di mana guru harus memahami terlebih dahulu latar belakang masing-masing siswa di kelasnya. Salah satu strategi yang disarankan oleh Santrock (2014: 177-180) untuk kelas multikultural adalah strategi pembelajaran yang berpusat pada isu. Isu yang diangkat dalam pembelajaran sebaiknya melibatkan ekuitas dan keadilan sosial. Lebih lanjut guru perlu meningkatkan hubungan antarsiswa dari kelompok latar belakang yang berbeda misalnya dengan strategi kelas Jigsaw di mana siswa dengan latar belakang berbeda saling bekerja sama dengan melakukan bagian khusus untuk mencapai tujuan umum. Di disi lain guru juga perlu menerapkan pembelajaran yang mengurangi bias dan meningkatkan toleransi.

Berdasarkan penjelasan di atas, nampak bahwa pembelajaran multikulturan sangat relevan untuk dibahas. Kesulitan pengelolaan kelas dengan karakteristik siswa yang beragam masih sering ditemukan di lapangan. Mengingat pentingnya ketercapaian tujuan pembelajaran, pemerataan, dan keadilan bagi semua siswa, maka bahasan lebih luas dan mendalam mengenai pembelajaran multikultural sangat penting dan menarik untuk didiskusikan. Penelitian ini bertujuan untuk mengkaji dan menguraikan urgensi pembelajaran multikultural khususnya di dunia pendidikan formal.

\section{Metode Penelitian}

Penelitian ini adalah penelitian kualitatif dengan metode telaah sistematis (systematic review). Sumber informasi berupa dokumen atau literatur terkait konsep pembelajaran multikultural. Dokumen atau literatur dapat berupa buku, artikel ilmiah, prosiding, laporan penelitian, dan dokumen akademik lainnya baik dalam lingkup nasional maupun dalam lingkup internasional. Dokumen atau literatur dianalisis secara sistematis menurut model Creswell. Kajian diawali dengan mengidentifikasi istilah kunci yang menjadi penuntun atau garis besar atau kerangka alur yang ditelaah secara konseptual, dilanjutkan dengan peletakan literatur pada kerangka alur tersebut, kemudian memilih dan memaknai konsep yang didapat serta menyarikan dan menghubungkan kedudukan konsep, diakhiri dengan penulisan hasil kajian. Total literatur yang dikaji sebanyak 58 dokumen. Hasil telaah disajikan dalam bentuk narasi yang tersambung dengan pembahasan sehingga kedudukannya disejajarkan.

\section{Hasil dan Pembahasan \\ 1. Konsep Multikultural}

Multikulturalisme adalah sistem keyakinan dan perilaku yang mengakui dan menghormati kehadiran kelompok yang beragam dalam suatu organisasi atau masyarakat, mengakui sosialbudaya yang berbeda, dan memungkinkan kontribusi selanjutnya dalam organisasi atau masyarakat (Sleeter and Grant, 1988). Multikulturalisme menghargai identitas budaya berbagai kelompok ketika anggota berpartisipasi dan berinteraksi dengan budaya dominan. Keragaman di tempat kerja, sekolah, universitas, atau komunitas dihargai dan dicari secara afiliatif. Hal tersebut memungkinkan individu untuk memilih keanggotaan dalam kelompok budaya dan sosial yang 
Rahmad Hidayat, Bunyamin, Elly Malihah

Vol 5 No 1

ISSN : 2541-6995

E ISSN : 2580-5517

terbaik dari identitas mereka, tanpa takut dikucilkan dari kelompok asli atau kelompok baru (Gollnick \& Chinn, 2013: 12).

Beach \& Tsotsos (1981) mendeskripsikan bahwa pendekatan multikultural seringkali dibawa ke dunia pendidikan. Konsep multikultural ini lebih ditekankan pada setiap proses di dalam pendidikan. Reagan (1984) menambahkan perkembangan budaya dan bahasa menjadi tantangan bagi para pendidik dalam penyelenggaraan pendidikan. Di Indonesia, dengan sekolahsekolah yang berkembang dan beragam, sangat penting bahwa pendidik dapat berpartisipasi efektif di lebih dari satu budaya. Ketika kita belajar untuk berfungsi dengan nyaman dalam budaya yang berbeda, kita harus dapat bergerak dari satu perspektif yang terkait dengan dominasi budaya. Kita harus dapat melintasi batas budaya dan mengintegrasikan budaya siswa ke dalam kelas. Memahami isyarat budaya berbagai kelompok meningkatkan kemampuan pendidik untuk bekerja dengan seluruh siswa dan membuat kita lebih peka terhadap pentingnya perbedaan budaya dalam mengajar.

\section{Pembelajaran Berbasis Multikultural}

Pembelajaran merupakan sebuah kegiatan guru mengajar atau membimbing siswa menuju proses pendewasaan diri (Suyono dan Hariyanto, 2014: 131). Berdasarkan definisi tersebut, pembelajaran lebih memfokuskan pada proses pendewasaan yang artinya mengajar dalam bentuk penyampaian materi tidak hanya bagaimana menyampaikan materi (transfer of knowledge), tetapi juga bagaimana menyampaikan nilai-nilai (transfer of value) dari materi yang diajarkan, sehingga bermanfaat untuk mendewasakan siswa. Pembelajaran juga didefinisikan sebagai kemampuan guru dalam mengorganisasikan pembelajaran yaitu dimulai dari perencanaan, pelaksanaan, hingga evaluasi pembelajaran. Artinya, secara institusional pembelajaran dituntut untuk dapat dilaksanakan secara efektif dan efesien oleh guru. Oleh sebab itu, guru dituntut mampu mengadaptasi dan mengembangkan berbagai teknik mengajar untuk berbagai macam perbedaan siswa dan karakteristiknya. Dengan demikian, konsekuensi dari pembelajaran dalam pengertian ini adalah tingkat pemahaman dan penguasaan guru tentang model-model dan metode yang dikembangkan dalam pembelajaran, untuk dipraktikkan dalam proses pembelajaran (Biggs dalam Sugihartono, dkk, 2007: 80-81).

Menurut Gollnick \& Chinn (2013: 4) "Multicultural education is an educational construct in which students' cultures are integrated into the curriculum, instruction, and classroom and school environment. It supports and extends the concepts of culture, diversity, equality, social justice, and democracy into the school setting. An examination of these concepts and their practical applications in schools is a first step in creating a classroom that is multicultural". Berdasarkan pernyataan ini berarti pembelajaran berbasis multikultural dapat diartikan sebagai konstruksi pembelajaran dimana budaya siswa diintegrasikan ke dalam kurikulum, proses pembelajaran, dan lingkungan sekolah. Ini mendukung dan memperluas konsep budaya, keanekaragaman, kesetaraan, keadilan sosial, dan demokrasi ke dalam pengaturan sekolah. Sedangkan menurut Rustan (2018: 247) pembelajaran berbasis multikultural adalah kebijakan dalam praktik pendidikan dalam mengakui, menerima, dan menegaskan perbedaan dan persamaan manusia yang dikaitkan dengan budaya, gender, ras, dan kelas sosial.

Pembelajaran multikultural ini diterapkan di lingkungan sekolah untuk memberikan pemahaman kepada siswa tentang keberagaman. Melalui pembelajaran berbasis multikultural, sikap dan pemikiran (mindset) siswa akan lebih terbuka untuk memahami dan menghargai keberagaman. Pembelajaran berbasis multikultural juga dapat didefinisikan sebagai pembelajaran 
Rahmad Hidayat, Bunyamin, Elly Malihah

Vol 5 No 1

ISSN : 2541-6995

E ISSN : 2580-5517

tentang keragaman kebudayaan dalam merespon perubahan demografis dan kultural lingkungan masyarakat tertentu bahkan dunia secara keseluruhan (Arifudin, 2007). Sejalan dengan pendapat Freire (2002) bahwa pendidikan bukanlah menara gading yang berusaha menjauhi realitas sosial dan budaya. Pendidikan menurutnya, harus mampu menciptakan tatanan masyarakat yang hanya mengagungkan prestise sosial sebagai akibat kekayaan dan kemakmuran yang dialaminya. Pembelajaran berbasis multikultural adalah suatu pendekatan progresif untuk melakukan transformasi pendidikan yang secara menyeluruh membongkar kekurangan, kegagalan, dan praktik-praktik diskriminasi dalam proses pendidikan (Arifudin, 2007). Dengan kata lain, pendidikan multikultural merupakan proses penanaman cara hidup menghormati dan toleran terhadap keragaman budaya yang ada di masyarakat plural. Pendidikan multikultural diharapkan terdapat kekenyalan dan kelenturan mental bangsa dalam menghadapi benturan konflik sosial.

Banks (2005: 3), menjelaskan bahwa multicultural education is at least three things: an idea or concept, an educational reform movement, and a process. Multicultural education incorporates the idea that alla students regardless of their gender and social class and their ethnic, racial, or cultural characteristics should have an equal opportunity to learn in school". Berdasarkan kalimat tersebut, ada tiga hal yang menjadi dasar apa itu pendidikan multikultural yaitu, ide atau konsep, gerakan perubahan pendidikan, dan proses pendidikan yang tujuannya adalah untuk mengubah struktur lembaga pendidikan agar siswa baik perempuan maupun pria, siswa berkebutuhan khusus, dan siswa yang merupakan anggota dari kelompok ras, etnis, dan kultur yang bermacam-macam dapat melaksanakan pendidikan dan mendapatkan kesempatan yang sama untuk mencapai prestasi akademik di sekolah. Banks (2008, p.32), mengidentifikasi ada lima dimensi pendidikan multikultural yang diperkirakan dapat membantu guru dalam mengimplementasikan beberapa program yang mampu merespon terhadap perbedaan, yaitu 1) content integration, 2) the knowledge construction process, 3) prejudice reduction, 4) an empowering school culture and social structure, dan 5) an equity pedagogy.

Pendidikan multikultural dikritik karena berfokus pada perbedaan daripada kesamaan di antara kelompok subjek didik. Ahli teori kritis memberikan argumen ini karena tidak cukup mampu menangani masalah kekuatan dan penindasan sehingga ada kesenjangan sejumlah kelompok untuk berpartisipasi secara adil dalam masyarakat. Di setidaknya tiga aliran pemikiran mendorong multikulturalis untuk berpikir kritis tentang masalah-masalah ini: pedagogi kritis, pendidikan anti-racist, dan teori ras kritis (Sleeter \& Bernal, 2004). Pedagogi kritis berfokus pada budaya kehidupan sehari-hari dan interaksi kelas, ras, dan jenis kelamin dalam perebutan kekuasaan kontemporer. Pendidikan anti-racist adalah konstruksi yang digunakan di Kanada dan sejumlah negara Eropa untuk menghilangkan praktik rasis seperti pelacakan, pendanaan yang tidak adil, dan segregasi di sekolah. Teori ras kritis berfokus pada rasisme untuk menentang penindasan ras, ketidaksetaraan rasial, dan hak istimewa kelompok tertentu (Howard, 2010). Lebih lanjut dijelaskan, pendidikan multikultural mempromosikan pemikiran kritis hal ini dan masalah lainnya untuk memastikan bahwa pendidikan melayani kebutuhan semua kelompok secara adil. Pendidikan multikultural disajikan selama ini mencoba untuk mengintegrasikan pandangan pedagogi kritis, pendidikan anti-racist, dan teori ras kritis.

Dengan lebih sederhana, Banks (1993) memberi penekanan pada pendidikan berbasis multikultural yakni demi keseimbangan (kesetaraan), integritas akademis, dan akurasi. Para pendidik diharapkan dapat fokus pada pengembangan, dimensi, dan tantangan pendidikan multikultural di kelas. Sejalan dengan hal ini, Banks \& Banks (2016) menyebutkan beberapa aspek yang perlu menjadi perhatian dalam penerapan pendidikan multikultural yakni tujuan 
Rahmad Hidayat, Bunyamin, Elly Malihah

Vol 5 No 1

ISSN : 2541-6995

E ISSN : 2580-5517

pembelajaran, kelas sosial dan agama, gender, ras, etnis, dan bahasa, kesetaraan untuk disabilitas, reformasi sosial kelas dan penilaian. Bennett (1986) menyatakan bahwa keragaman budaya mempengaruhi manusia pada banyak aspek, termasuk subjek didik. Oleh karena itu, keragaman karakteristik subjek didik perlu menjadi perhatian bagi pendidik. Selanjutnya, hasil penelitian Sleeter (2010) mengusulkan empat tipe ideal untuk pendidikan multikultural yang baik antara lain mengapresiasi perbedaan budaya bangsa sendiri, mengapresiasi perbedaan budaya secara internasional, keadilan sosial dan anti-diskriminasi, keadilan global dan anti-diskriminasi. Beberapa hal ini perlu menjadi perhatian pendidik dalam pembelajaran di kelasnya.

\section{Eksistensi Pembelajaran Multikultural}

Secara sempit pendidikan multikulturan merujuk pada pembelajaran yang berbasis multikultural. Wilhelm (1998) dalam penelitiannya tentang masalah-masalah terkait pembelajaran multikultural menyimpulkan hal yang senada dengan beberapa penjelasan para ahli sebelumnya yakni pembelajaran multikultural mempertimbangkan dan menangani isu etnis, kelas sosial, gender, dan sebagainya untuk tujuan keseimbangan. Masing-masing aspek dalam pembelajaran multikultural ini dapat dianalisis dan dibahas secara terpisah. Di akhir kajiannya, Wilhelm menyatakan jika pembelajaran multikultural berusaha membentuk proses pembelajaran dengan cara yang substantif, diperlukan dukungan untuk menjembatani antara praktiknya dengan kesenjangan retoris dalam proses pembelajaran, kurikulum dan kebijakannya.

Meninjau penerapan pendidikan multikultural secara internasional, telah banyak penelitian serta pengembangan yang dilakukan diberbagai negara. Beberapa penelitian yang terkait penerapan pendidikan multikultural di luar Indonesia antara lain penelitian Stübig (1995) tentang pendidikan multikultural di Inggris, Kahn (2008) dan Mahiri (2017) di United States, Karatas (2015) di Antalya, Chang (2012) dan Shen (2019) di Korea, Tran \& Johnston-Guerrero (2016) di Ohio, dan Jackson \& Nesterova (2017) di Hong Kong. Beberapa hasil penelitian ini memberikan argumentasi dan rekomendasi yang hampir sama bahwa pendidikan multikultural memberikan kesempatan yang adil bagi seluruh subjek belajar meskipun subjek tersebut berasal dari kelompok budaya minoritas.

Kajian pada tulisan ini difokuskan pada kondisi multikultural dan pembelajaran berbasis multikultural di Indonesia dengan kenyataan bahwa di Indonesia terdapat keberagaman suku, etnis, ras, agama, budaya, bahasa, dan sebagainya yang mudah sekali dijumpai di dunia pendidikan khususnya pendidikan formal. Keberagaman di Indonesia dinyatakan oleh beberapa penelitian diantaranya Arifin, Hasbullah, \& Pramono (2017) yang menyelidiki tentang keberadaan etnis Cina yang ada di kalangan masyarakat Indonesia. Berdasar hal ini dapat disimpulkan bahwa etnis Cina juga ada di sekolah-sekolah yang tersebar di seluruh wilayah Indonesia. Kemudian Harjatanaya \& Hoon (2020) melaporkan tentang kebijakan pendidikan multikultural terkait minoritas etnis Cina yang ada di Indonesia. Parker, Hoon, \& Raihani (2014) melakukan sosialisasi antar-etnis dan antar-agama khususnya terkait perkawinan di Indonesia. Hoon (2006) lebih khusus melaporkan perkawinan antar-etnis dan dilemanya. Di samping penelitian tentang etnis, juga terdapat beberapa penelitian terhadap aspek gender yang memberikan dukungan penerapan pembelajaran multikultural di kelas diantaranya adalah penelitian Parker (2011). Kemudian ada juga penelitian terkait agama dalam konteks multikultural di Indonesia oleh Hoon (2017). Terkait pembelajaran multikultural ini, Hornaday (1992) pernah menyimulasikan pembelajaran multikultural di Indonesia dengan bantuan program komputer. 


\section{Urgensi Pembelajaran Multikultural di Indonesia}

Pembelajaran multikultural menuntut penanaman nilai-nilai kesetaraan dan kebersamaan di dalam kelas. Nlai-nilai kesetaraan dan kebersamaan ini mendukung keseimbangan di kelas dan menekan sikap superioritas. Seperti yang telah diuraikan sebelumnya, kelas multikultural terkait pemberian perhatian pada aspek kesukuan, ras, agama, gender, budaya, bahasa, dan sebagainya. Kelompok tertentu diharapkan tidak merasa lebih tinggi atau lebih unggul dari kelompok lain sehingga setiap subjek memperoleh kesempatan belajar yang sama. Setiap subjek belajar perlu berfokus pada bagaimana menyelesaikan tugas-tugas belajar untuk mencapai tujuan yang sama, meskipun dari kelompok yang berbeda-beda. Kondisi ini memaksa seseorang untuk lebih memahami kelompok lain maupun orang lain agar tujuan dapat tercapai dengan baik sehingga dapat tercapai keseimbangan kelas. Menurut Banks (1993) keseimbangan kelas ini merupakan salah satu aspek utama yang perlu dimunculkan di dalam kelas multikltural.

Pembelajaran multikultural sangat penting dan perlu diterapkan segera secara tepat di Indonesia. Ubaedillah (2018) mengungkapkan bahwa pendidikan untuk umat muslim di Indonesia dapat menjadi contoh pendidikan muslim dalam skala global. Dalam hal ini, pendidikan untuk muslim tidak terlepas dari aspek multikulturalnya. Osler (2015) menyatakan bahwa konteks multikultural dapat membawa keadilan dan kesetaraan dan Rios \& Markus (2011) menambahkan pembelajaran multikultural dapat dianggap sebagai hak asasi manusia. Kemudian, Jun (2016) menyarankan agar pembelajaran berbasis multikultural segera dilaksanakan. Demikian pula Gollnick \& Chinn (2017) dan Jeffcoate (1981), memberikan penguatan bahwa pembelajaran berbasis multikultural sangat penting dan sangat direkomendasikan untuk diterapkan di kelas dengan keberagaman karakteristik subjek belajarnya. Di kelas-kelas di sekolah-sekolah dan banyak perguruan tinggi di Indonesia sangat mudah dijumpai keberagaman karakteristik subjek belajarnya sehingga pembelajaran multikultural menjadi sangat penting untuk diterapkan.

Menurut Unwanullah (2012), pembelajaran dengan perspektif multikultural merupakan tranformasi pendidikan untuk mengatasi konflik masyarakat. Di Indonesia, banyak dijumpai kasus konflik dan tawuran antar-siswa atau antar-mahasiswa kemungkinan besar karena tidak memahami keberagaman, nilai-nilai kesetaraan dan kebersamaan seharusnya sudah ditanamkan melalui proses pembelajaran. Pembelajaran multikultural dapat menjadi solusi terbaik untuk mengantisipasi kasus semacam ini. Syaifuddin (2006) mengajukan permasalahan bagaimana membumikan multikulturalisme di Indonesia.

Pendidikan multikultural merupakan proses penanaman nilai-nilai dan cara hidup menghormati, tulus, dan toleran terhadap keragaman budaya yang hidup di tengah-tengah masyarakat plural. Dengan pendidikan multikultural, diharapkan adanya kekenyalan dan kelenturan mental bangsa dalam menghadapi benturan konflik sosial. Pendidikan multikultural tidak harus berdiri sendiri, tetapi dapat terintegrasi dalam mata pelajaran dan proses pendidikan yang ada di sekolah termasuk keteladanan para guru dan warga sekolah secara umum. Oleh karena itu, pendidikan multikultural haruslah mencakup hal yang berkaitan dengan toleransi, perbedaan etno-kultural dan agama, bahaya diskriminasi, penyelesaian konflik dan mediasi, HAM, demokrasi dan pluralitas, kemanusiaan universal, dan sebagainya yang mengantarkan terbentuknya masyarakat yang cinta perdamaian serta menghargai perbedaan.

Dalam konteks implementasinya, pendidikan multikultural merupakan tindakan-tindakan

yang sinergis baik di sekolah atau perguruan tinggi, di keluarga, maupun di masyarakat yang digerakkan oleh sekolah atau perguruan tinggi melalui pengkondisian interaksi subjek belajar. Agar subjek belajar dapat berinteraksi secara baik dan berlandaskan nilai-nilai kesetaraan dan 
Rahmad Hidayat, Bunyamin, Elly Malihah

Vol 5 No 1

ISSN : 2541-6995

E ISSN : 2580-5517

kebersamaan dengan sesama di lingkungan hidupnya, maka subjek perlu dibekali kemampuan eksis dan dapat menyesuaikan diri dalam keberagaman yang ada, serta menjunjung tinggi nilainilai kehidupan bersama. Dengan demikian, mereka mampu menerima dan menyikapi perbedaan dengan baik. Dari uraian ini dan uraian sebelumnya, pembelajaran berbasis multikultural menjadi pilihan terbaik dalam kondisi multikultural di Indonesia. Selain itu, pembelajaran multikultural menurut Rohman \& Ningsih (2018) juga dapat menjadi penguatan identitas nasional di era revolusi industri 4.0 .

Pentingnya pembelajaran berbasis multikultural juga didukung oleh banyaknya penelitian yang berfokus pada penerapan pembelajaran berbasis multikultural di Indonesia. Pembelajaran berbasis multikultural di sekolah keagamaan dilakukan oleh Azzuhri (2012), Raihani (2012), dan Rustiawan (2017) yang secara khusus ditujukan pada sekolah berbasis keislaman dan berusaha menguniversalkan pendidikan agama dalam ranah ke-Indonesia-an. Kemudian secara umum, penelitian terkait pembelajaran berbasis multikultural di Indonesia dilakukan oleh Hanum \& Rahmadonna (2009), Amirin (2012), Al-Arifin (2012), Noe, Affandi, Malihah, \& Sunatra (2018), dan Tjipto \& Bernardo (2019). Secara keseluruhan, penelitian-penelitian ini membuktikan bahwa pembelajaran berbasis multikultural cocok dan sangat layak diterapkan di Indonesia.

Penerapan pembelajaran multikultural perlu penyesuaian proses pembelajaran, kurikulum dan kebijakannya (Wilhelm, 1998). Saat ini di Indonesia, pada jenjang pendidikan dasar dan menengah diberlakukan kurikulum 2013 yang telah beberapa kali direvisi. Perubahan yang cukup mencolok pada kurikulum ini dari kurikulum sebelumnya adalah pada penguatan standar proses pembelajaran. Menanggapi kebijakan ini, Elihami (2019: 79) mengatakan bahwa kreativitas guru (pendidik) sangat perlukan untuk membimbing siswa memperoleh pengalaman belajar yang bermakna. Di samping itu, Apriono (2013: 292) menyatakan bahwa guru dalam perencanaan dan pelaksanaan pembelajarannya perlu mempertimbangkan keberagaman karakteristik subjek belajar. Dalam hal ini, strategi pembelajaran kooperatif dan atau kolaboratif dapat menjadi pilihan yang cocok untuk diterapkan. Dengan kata lain, pada pembelajaran multikultural sangat dekat dengan model pembelajaran kooperatif dan kolaboratif karena memiliki asumsi dasar yang sama yakni kesetaraan kesempatan belajar untuk seluruh subjek belajar. Pembelajaran multikultural selain di tingkat kelas juga dapat dilakukan terintegrasi di tingkat subjek pembelajaran tertentu (Hanum \& Raharja, 2013) di mana selanjutnya dapat dikembangkan model pembelajaran multikultural untuk setiap subjek pembelajaran. Pengembangan model pembelajaran multikultural secara umum di sekolah dan atau secara khusus di setiap subjek pelajaran dapat menjadi pendukung implementasi pendidikan multikultural di Indonesia. Pengembangan model pembelajaran multikultural menjadi penting dan diperlukan mengingat model ini belum terkonstruksi secara baku seiring dengan pentingnya pembelajaran multikultural.

\section{Kesimpulan}

Kelompok etnis, ras, budaya, suku, dan agama di Indonesia memiliki keragaman yang nampak mencolok sehingga masyarakatnya secara sederhana dapat disebut sebagai masyarakat multikultural. Realitas multikultural tersebut berhadapan dengan kebutuhan untuk merekonstruksi kembali kebudayaan nasional Indonesia di berbagai bidang yang dapat menjadi daya pemersatu yang mengikat seluruh keragaman etnis dan budaya tersebut. Salah satu upaya yang memiliki pengaruh besar adalah bidang pendidikan yakni dengan implementasi pendidikan multikultural. Pendidikan multikultural dilandaskan pada kenyataan bahwa pendidikan tidak bisa terlepas dari 
Rahmad Hidayat, Bunyamin, Elly Malihah

Vol 5 No 1

ISSN : 2541-6995

E ISSN : 2580-5517

realitas sosial dan budaya. Melalui pendidikan multikultural, nilai-nilai kesetaraan dan kebersamaan dapat ditanamkan dan sikap superioritas yang menghambat pemahaman keberagaman dapat dihilangkan. Dalam hal ini, dari aspek latarbelakangnya, diharapkan kelompok tertentu diharapkan tidak merasa lebih tinggi dari kelompok lain. Pendidikan multikultural menjadi sangat penting untuk diterapkan sebab pendidikan multikultural mampu menjadi solusi terbaik dalam menangani keragaman yang ada, baik suku, ras, agama, etnis, status sosial-ekonomi, budaya, dan sebagainya. Oleh karena itu, pendidikan di sekolah, baik umum maupun yang berlandaskan agama penting sekali menerapkan pembelajaran multikultural dan mengimplementasikannya melalui berbagai cara dalam proses pendidikan.

Pendidikan multikultural secara sempit merujuk pada pembelajaran multikultural. Pembelajaran multikultural sangat penting dan perlu diimplementasikan di berbagai tingkat pendidikan, mulai dari pendidikan dasar hingga perguruan tinggi. Pembelajaran multikultural dapat diintegrasikan pada semua subjek pelajaran, kemudian untuk mengimplementasikannya diperlukan suatu pedoman yang dirancang bagi guru baik oleh guru sendiri, tim guru, maupun ahli/peneliti. Implementasi pembelajaran multikultural sangat dekat dengan model pembelajaran kooperatif dan kolaboratif yang menekankan pada kesadaran akan kesetaraan dan kebersamaan dalam proses belajar. Model ini membiasakan sunjek belajar berinteraksi dengan subjek belajar lain dalam kelompok dan antar kelompok. Setiap subjek bekerja dan berupaya menyelesaikan tugas-tugas belajar untuk mencapai tujuan yang sama, baik dalam satu kelompok maupun berbeda kelompok. Kondisi ini menuntut seseorang untuk lebih memahami subjek dalam kelompok dan kelompok lain agar tujuan dapat tercapai dengan baik. Selanjutnya, untuk mendukung implementasi pendidikan multikultural perlu dikembangkan model pembelajaran multikultural secara umum di sekolah dan atau secara khusus di setiap subjek pelajaran.

\section{Referensi}

Al-Arifin, A. H. (2012). Implementasi pendidikan multikulutral dalam praksis pendidikan di Indonesia. Jurnal Pembangunan Pendidikan: Fondasi dan Aplikasi, 1(1).

Amirin, T. M. (2012). Implementasi pendekatan pendidikan multikultural kontekstual berbasis kearifan lokal di Indonesia. Jurnal pembangunan pendidikan: Fondasi dan aplikasi, 1(1).

Apriono, D. (2013). Pembelajaran Kolaboratif: Suatu Landasan untuk Membangun Kebersamaan dan Keterampilan. Diklus, 17(1), 292-304.

Arifin, E. N., Hasbullah, M. S., \& Pramono, A. (2017). Chinese Indonesians: how many, who and where?. Asian Ethnicity, 18(3), 310-329.

Arifudin, I. (2007). Urgensi implementasi pendidikan multikultural di sekolah. INSANIA: Jurnal Pemikiran Alternatif Kependidikan, 12(2), 220-233.

Azzuhri, M. (2012). Konsep Multikulturalisme Dan Pluralisme Dalam Pendidikan Agama (Upaya Menguniversalkan Pendidikan Agama dalam Ranah Keindonesiaan). In Forum Tarbiyah (Vol. 10, No. 1, pp. 13-29). Fakultas Tarbiyah IAIN Pekalongan.

Banks, J. (2008). An introduction to multicultural education. United States: Pearson

Banks, J. A. (1993). Multicultural education: Development, dimensions, and challenges. The Phi Delta Kappan, 75(1), 22-28.

Banks, J. A., \& Banks, C. A. M. (2016). Multicultural education: Issues and perspectives $9^{\text {th }}$ ed. New York: John Wiley \& Sons, Inc.

Banks, J.A., \& Banks, M.C. (2005). Multicultural education; Issues and perspectives 5th ed. New York: John Wiley \& Sons, Inc.

Beach, D. M., \& Tsotsos, P. (1981). A multicultural approach to education and architecture. Journal of Multilingual \& Multicultural Development, 2(3), 195-201.

Bennett, C. I. (1986). Comprehensive multicultural education: Theory and practice. Boston: Allyn and Bacon. 
Capuzzi, D. \& Gross, D.R. 1997. Introduction to The Counseling Profession. Second Edition. Boston: Allyn and Bacon.

Chang, I. S. (2012). Multicultural education in Korea: Its origin, status, and direction. Multicultural Education Review, 4(2), 60-90.

Elihami, E. (2019). Implementasi Layanan Bimbingan Kelompok dalam Meningkatkan Higher of Think Mahasiswa Berbasis Kampus Merdeka. EduPsyCouns: Journal of Education, Psychology and Counseling, 1(1), 79-86.

Freire, Paulo. 2002. Politik Pendidikan: Kebudayaan, Kekuasaan, dan Pembebasan. Terjemahan Agung Prihantoro. Yogyakarta: Pustaka Pelajar.

Gollnick, D.M. \& Chinn, P.C. (2017). Multicultural Education in A Pluralistic Society, Tenth Edition. USA: Pearson Education, Inc.

Hanum, F., \& Raharja, S. (2013). Pengembangan model pembelajaran multikultural terintegrasi mata pelajaran IPS di Sekolah Dasar. Jurnal Penelitian Ilmu Pendidikan, 6(2).

Hanum, F., \& Rahmadonna, S. (2009). Implementasi Model Pembelajaran Multikultural di Sekolah Dasar di Propinsi Daerah Istimewa Yogyakarta. Artikel Multikultural-Stranas, 2, 1-17.

Harjatanaya, T. Y., \& Hoon, C. Y. (2020). Politics of multicultural education in Post-Suharto Indonesia: A study of the Chinese minority. Compare: a journal of comparative and international education, 50(1), 18-35.

Hoon, C. Y. (2006). Assimilation, multiculturalism, hybridity: The dilemmas of the ethnic Chinese in post-Suharto Indonesia. Asian Ethnicity, 7(2), 149-166.

Hoon, C-Y. (2017). Putting Religion into Multiculturalism: Conceptualising Religious Multiculturalism in Indonesia. Asian Studies Review, 41(3), 476-493.

Hornaday, R. W. (1992). Multicultural Experiential Learning: A Computer Simulation in Indonesia. Journal of Education for Business, 68(2), 105-109.

Jackson, L., \& Nesterova, Y. (2017). Multicultural Hong Kong: alternative new media representations of ethnic minorities. Multicultural Education Review, 9(2), 93-104.

Jeffcoate, R. (1981). Why multicultural education?. Education 3-13, 9(1), 4-7.

Joesoef, S. (1992). Konsep Dasar Pendidikan Luar Sekolah. Cetakan ke-1. Jakarta: Bumi Aksara.

Jun, E. J. (2016). Multicultural education course put into practice. Multicultural Education Review, 8(2), 83-98.

Kahn, M. (2008). Multicultural education in the United States: reflections. Intercultural Education, 19(6), 527-536.

Karatas, S. (2015). Teachers' views on multicultural education: Sample of Antalya. The Anthropologist, 19(2), 373380.

Koentjaraningrat. 1989. Pengantar Ilmu Antropologi. Jakarta : Aksara baru

Kusmaryani, R. E. (2006). Pendidikan multikultural sebagai alternatif penanaman nilai moral dalam keberagaman. Paradigma, $1(02)$.

Mahiri, J. (2017). Introduction: multicultural education and micro-cultural youth. Multicultural Education Review, 9(2), 79-82.

Mawardi, M. (2014). Pemberlakuan Kurikulum SD/MI Tahun 2013 dan Implikasinya Terhadap Upaya Memperbaiki Proses Pembelajaran Melalui PTK. Scholaria: Jurnal Pendidikan dan Kebudayaan, 4(3), 107-121.

Noe, W., Affandi, I., Malihah, E., \& Sunatra, S. (2018). The dynamics of multicultural values of Banuroja community in building social integration a socio-cultural ethnographic study in Gorontalo. Journal of Human Behavior in the Social Environment, 28(6), 758-770.

Osler, A. (2015). The stories we tell: Exploring narrative in education for justice and equality in multicultural contexts. Multicultural Education Review, 7(1-2), 12-25.

Parker, L. (2011). Where are the women in multiculturalism? Contributions on culture and religion from an anthropologist of multiculturalism in Indonesia. Australian Feminist Studies, 26(70), 433-452.

Parker, L., Hoon, C. Y., \& Raihani. (2014). Young people's attitudes towards inter-ethnic and inter-religious socializing, courtship and marriage in Indonesia. South East Asia Research, 22(4), 467-486.

Pradipto. Y.D. 2005. Pemahaman Multikultural dan Pendidikan Multikultural. Kompas. Minggu, 20 Maret 2020.

Raihani. (2012). Report on multicultural education in pesantren. Compare: A Journal of Comparative and International Education, 42(4), 585-605.

Reagan, T. (1984). Multiculturalism: An educational perspective. Educational Studies, 15(2), 101-107.

Rios, F., \& Markus, S. (2011). Multicultural education as a human right: Framing multicultural education for citizenship in a global age. Multicultural Education Review, 3(2), 1-35.

Rohman, A., \& Ningsih, Y. E. (2018, October). Pendidikan multikultural: penguatan identitas nasional di era revolusi industri 4.0. In Prosiding Seminar Nasional Multidisiplin (Vol. 1, pp. 44-50). 
Rustan, E. (2018). Pembelajaran Bahasa dan Sastra Daerah Berbasis Multikultural dalam Mewujudkan Pendidikan yang Berkarakter di Era Globalisasi. (n.d.).

Rustiawan, H. (2017). Pendidikan Multikultural Dalam Sistem Pendidikan Islam. SAINTIFIKA ISLAMICA: Jurnal Kajian Keislaman, 2(02), 83-94.

Sanjaya, W. (2014). Strategi Pembelajaran Berorientasi Standar Proses Pendidikan. Cetakan ke-11. Jakarta: Kencana Prenadamedia Group.

Santrock, J.W. (2014). Psikologi Pendidikan (Educational Psychology), Edisi 5 Buku 1. Terjemahan Harya Bhimasena. Jakarta: Salemba Humanika.

Shen, S. (2019). Teaching 'multiculturally': geography as a basis for multicultural education in Korea. Multicultural Education Review, 11(1), 37-58.

Sleeter, C. E. (2010). Probing beneath meanings of multicultural education. Multicultural Education Review, 2(1), 124.

Sleeter, C.E. \& Grant, C.A. 1988. Making Choice for Multicultural Education, File Approaches to Race, Class, and Gender. New York. MacMillan Publishing Compeny.

Stübig, H. (1995). Multicultural education in England. European education, 27(3), 24-35.

Sugihartono, dkk. 2007. Psikologi pendidikan. Yogyakarta: UNY Press

Suyono dan Hariyanto. 2014. Belajar dan Pembelajaran Teori dan Konsep Dasar. Bandung: PT Remaja Rosdakarya.

Syaifuddin, A. F. (2006). Membumikan multikulturalisme di Indonesia. Jurnal Antropologi Sosial Budaya ETNOVISI, 2(1), 3-10.

Tjipto, S., \& Bernardo, A. B. (2019). Constraints in the meanings of lay theories of culture in a culturally homogeneous society: A mixed-methods study on multiculturalism and polyculturalism in Wonosobo, Indonesia. Cogent Psychology, 6(1), 1569835.

Tran, V. T., \& Johnston-Guerrero, M. P. (2016). Is Transracial the Same as Transgender? The Utility and Limitations of Identity Analogies in Multicultural Education. Multicultural Perspectives, 18(3), 134-139.

Ubaedillah, A. (2018). Civic Education for Muslim Students in the Era of Democracy: Lessons Learned from Indonesia. The Review of Faith \& International Affairs, 16(2), 50-61.

Unwanullah, A. (2012). Tranformasi Pendidikan untuk Mengatasi Konflik Masyarakat dalam Perspektif Multikultural. Jurnal Pembangunan Pendidikan: Fondasi dan Aplikasi, 1(1).

Wilhelm, R. W. (1998). Issues in multicultural education. Curriculum journal, 9(2), 227-246. 